\title{
Occurrence of Toxoplasma gondii and risk factors for infection in pigs raised and slaughtered in the Triângulo Mineiro region, Minas Gerais, Brazil ${ }^{1}$
}

\author{
Fabielle Marques-Santos ${ }^{2}$, Maria Regina R. Amendoeira ${ }^{3}$, Kênia F. Carrijo ${ }^{4}$, \\ João Paulo A.F. Santos ${ }^{5}$, Igor F. Arruda ${ }^{2}$, Adriana P. Sudré2, Beatriz Brener ${ }^{2}$ \\ and Patricia R. Millar ${ }^{2,3 *}$
}

\begin{abstract}
Marques-Santos F., Amendoeira M.R.R., Carrijo K.F., Santos J.P.A.F., Arruda I.F., Sudré A.P., Brener B. \& Millar P.R. 2017. Occurrence of Toxoplasma gondii and risk factors for infection in pigs raised and slaughtered in the Triângulo Mineiro region, Minas Gerais, Brazil. Pesquisa Veterinária Brasileira 37(6):570-576. Laboratório de Parasitologia, Departamento de Microbiologia e Parasitologia, Universidade Federal Fluminense, Rua Vital Brazil Filho 64, Santa Rosa, Niterói, RJ 24230-340, Brazil. E-mail: patriciariddell@vm.uff.br

The Triângulo Mineiro region from Minas Gerais state, is an important meat-exporting region of Brazil and data about Toxoplasma gondii infection in pigs raised and slaughtered in this area are scarce. Therefore, the aim of this study was to evaluate the occurrence of $T$. gondii in swine and establish the risk factors associated with the infection. Samples were collected from 600 pigs raised under intensive system in farms located at three different counties (Carmo do Paranaíba, Patrocínio and Perdizes). The samples were submitted to indirect hemagglutination antibody test with dilution of 1:32 and to indirect immunofluorescence antibody test with a cutoff of 1:64. The occurrence of positive pig was $3.3 \%(n=20)$ and $51.8 \%(n=311)$ respectively. A significant difference was observed between toxoplasmatic infection and factors such as lineage, animal origin, size of the farm, collective raising with others species, presence of rodents and type of water offered $(\mathrm{p} \leq 0.05)$. There was no difference between gender and the farm goals. The results demonstrated an occurrence of anti- $T$. gondii antibodies higher than expected for intensive pig raising system on the studied area, which could indicate a possible sanitary management problem on the studied proprieties. Improvements on the raising techniques are necessary to reduce $T$. gondii infection sources.
\end{abstract}

INDEX TERMS: Toxoplasmosis, Toxoplasma gondii, serology, IHA, IFAT, swine.

RESUMO.- [Ocorrência e fatores de risco da infecção por Toxoplasma gondii em suínos criados e abatidos na região do Triângulo Mineiro, Minas Gerais, Brasil.]

\footnotetext{
${ }^{1}$ Received on August 25, 2016.

Accepted for publication on January 31, 2017.

${ }^{2}$ Laboratório de Parasitologia, Departamento de Microbiologia e Parasitologia (MIP), Universidade Federal Fluminense (UFF), Rua Vital Brazil Filho 64, Santa Rosa, Niterói, RJ 24230-340, Brazil. *Corresponding author: patriciariddell@vm.uff.br

${ }^{3}$ Laboratório de Toxoplasmose e outras Protozoonoses (LabTOXO), Instituto Oswaldo Cruz (Fiocruz), Avenida Brasil 4365, Manguinhos, Rio de Janeiro, RJ 21040-360, Brazil.

${ }^{4}$ Faculdade de Medicina Veterinária, Universidade Federal de Uberlândia (UFU), Campus Santa Mônica, Av. João Naves de Ávila 2121, Uberlândia, MG 38400-902, Brazil.

${ }^{5}$ Veterinário autônomo graduado pela UFU, Av. João Naves de Ávila 2121, Uberlândia, MG 38400-902, Brazil.
}

A região do Triângulo Mineiro, no estado de Minas Gerais, é uma importante região exportadora de carne do Brasil e pesquisas sobre a infecção por Toxoplasma gondii em suínos criados e abatidos nesta região são escassos. Portanto, o objetivo deste estudo foi avaliar a ocorrência de T. gondii nesses animais e estabelecer os fatores de risco associados com a infecção. Foram coletadas amostras de 600 suínos criados sob sistema intensivo, em fazendas localizadas em três municípios diferentes (Carmo do Paranaíba, Patrocínio e Perdizes). As amostras foram submetidas à Hemaglutinação Indireta com diluição de 1:32 e à Reação de Imunofluorescência Indireta com ponto de corte 1:64. A ocorrência de suínos positivos foi de 3,3\% (n=20) e 51,8\% (n=311), respectivamente. Foi observada diferença significativa entre a infecção toxoplásmica e fatores como linhagem, procedência dos animais, tamanho das propriedades, criação 
em conjunto com outras espécies, presença de roedores e tipo de água consumida $(\mathrm{p} \leq 0,05)$. Não houve diferenças estatísticas entre o sexo e finalidade de produção em relação à infecção por T. gondii. Os resultados demonstraram uma ocorrência de anticorpos anti-T. gondii superior à esperada em criações intensivas de suínos na região estudada, o que poderia indicar uma possível falha no manejo sanitário das propriedades estudadas. Melhorias nas técnicas de criação são necessárias para redução das fontes de infecção por $T$. gondii nos rebanhos.

TERMOS DE INDEXAÇÃO: Toxoplasmose, Toxoplasma gondii, sorologia, HAI, RIFI, suíno.

\section{INTRODUCTION}

Toxoplasma gondii is an obligatory intracellular parasite and is the etiological agent of toxoplasmosis, a zoonosis present worldwide that affects human and other warm-blooded animals (mammals and birds) (Elmore et al. 2010). The infection by $T$. gondii in farm animals is important because infected animals can act as direct or indirect source of infection to human. Also, toxoplasmosis can cause reproductive disorders such as abortion, neonatal death, and congenital defects leading to great economic losses (Sawadogo et al. 2005, Yu et al. 2007). The occurrence of T. gondii infection in animals can be a good parameter to alert for problems in rural areas since they are in direct contact with the environment (Amendoeira et al. 1999, Jiang et al. 2012).

Among farms animals, the pig is the most frequently infected and in several countries, including Brazil, its meat is considered the main transmission route to humans (Dubey et al. 2005, Dubey \& Jones 2008, Dubey 2009). Viable for$\mathrm{ms}$ of the parasite have been isolated from a great variety of meat products and serological studies in Brazil showed a wide distribution of this infection in pigs (Bonna et al. 2006, Millar et al. 2008, Muraro et al. 2010, Azevedo et al. 2010, Valença et al. 2011, Sousa et al. 2014).

The proportion of the human population infected by ingesting oocysts present in the environment or by raw or undercooked meat is unknown. It is not yet possible to determine the most important infection source for each individual. However, Dubey et al. (2005) suggest that in some regions the ingestion of raw or undercooked pig meat products with T. gondii cysts would be the main transmission route to humans. According to Fajardo et al. (2013), although detection of $T$. gondii in animal meat is an important short term measure, control strategies can only be performed with a deeper knowledge about the epidemiology of toxoplasmosis and few studies were conducted to study and identify the risk factors related to T. gondii infection in animals used for human consumption. The identification of these risk factors is critical for the development of raising systems that properly promote animal health and consequently avoid the production of meat containing infective forms of this parasite.

Minas Gerais state has a great contribution to pig industry in Brazil, nevertheless studies regarding the epidemiology of toxoplasmosis in pigs are scarce. The few studies on Minas Gerais state are mostly old (Schenk et al. 1977,
Passos et al. 1984, Guimarães et al. 1992, Pezerico et al. 2007), with only one recent study published by Almeida et al. (2015). Although Minas Gerais state has a total of more than five million pigs in raising systems, and the TriânguloMineiro region is considered the biggest pig raising area of Brazil, with $85 \%$ of the production destined to the export market (IBGE 2012, IBGE 2014), there are no studies about toxoplasmic infection in pigs raised and slaughtered in this area. Thus, the aim of this research is to evaluate the occurrence of Toxoplasma gondii in these animals and to establish risk factors associated with infection

\section{MATERIALS AND METHODS}

The studied animals were raised and slaughtered in Triângulo Mineiro, an important region in Brazilian pig industry. Geographical location of this region is as follows: $18^{\circ} 18^{\prime}$ and $20^{\circ} 27^{\prime}$ South and longitude $47^{\circ} 28^{\prime}$ and $51^{\circ} 30^{\prime}$ 'West. All pigs, 311 females and 289 males, were about 160 days-old and were feed exclusively with ration and raised under an intensive system. Serum samples were collected between May and July 2014 in three proprieties, each one located in a different county of Triângulo Mineiro region (Carmo do Paranaíba, Patrocínio, and Perdizes). The animals of all proprieties were slaughtered in abattoirs with official sanitary inspection service and therefore authorized to commercialize the products throughout national territory.

The number of samples was determined by Epi-info software based on the total population of pigs in the studied region calculated by Statistic and Geographic Brazilian Institute (IBGE 2012). The reference point was an expected prevalence of 50\%, confidence interval of $95 \%$, and absolute error of $5 \%$. The minimum number of animals considered representative of the studied population by sample calculation (Epi Info 6) was 385 . However, a total of 600 samples were randomly collected, 445 from Patrocínio, 120 from Carmo do Paranaíba, and 35 from Perdizes, and the animals lineages were respectively ADB, Agroceres PIC and unknown.

Blood samples were collected from animals approved in ante-mortem inspection by the official sanitary inspection. The samples $(10 \mathrm{~mL})$ were collected at exsanguination area of the abattoir in proper identified flasks without anticoagulant. The samples were rest at room temperature until clot retraction and then were centrifuged (1000g for 10 minutes). Serum was separated, kept in sterile flask at $-20^{\circ} \mathrm{C}$ and later forwarded to the Parasitological Immunodiagnosis Laboratory of the Microbiology and Parasitology Department of Universidade Federal Fluminense and to the Toxoplasmosis and other protozoan diseases Laboratory of IOC, Fiocruz. The samples arrived frozen at these laboratories, where the indirect hemagglutination antibody test (IHA) and indirect immunofluorescence antibody test (IFAT) for anti- $T$. gondii antibody detection were respectively performed. The IHA test was performed using a commercial kit (TOXO-HAI ${ }^{\circledR}$, WAMA) with dilution of $1: 32$, the protocol was performed according to manufacture instructions. The IFAT was performed according to Camargo (1964). Taquizoits from RH strain of T. gondii (Sabin 1941) were used as antigen. Serum samples previously tested by IFAT were used as positive and negative control. Animals were considered positive with antibody titration $\geq 64$.

The farm owners and/or abattoir technical manager answered an epidemiological questionnaire regarding the follow information about the animals raising system: age, gender, lineage, diet, contact with cats and rodents, purpose of the animals, type of raising system, type of water offered to the animals, and dewor- 
Table 1. Occurrence of anti-Toxoplasma gondii antibodies in serum samples of pigs slaughtered in Triângulo Mineiro region-MG during May-July 2014, according to their origin

\begin{tabular}{|c|c|c|c|c|c|c|}
\hline \multirow[t]{2}{*}{ Farm } & \multirow[t]{2}{*}{ Location } & \multirow[t]{2}{*}{ Samples (n) } & \multicolumn{2}{|c|}{ IHA } & \multicolumn{2}{|c|}{ IFAT } \\
\hline & & & $\begin{array}{c}\text { Reactives } \\
\mathrm{n}(\%)\end{array}$ & $\begin{array}{c}\text { Non-Reactives } \\
\mathrm{n}(\%)\end{array}$ & $\begin{array}{c}\text { Reactives } \\
\mathrm{n}(\%)\end{array}$ & $\begin{array}{c}\text { Non-Reactives } \\
\mathrm{n}(\%)\end{array}$ \\
\hline I & Carmo do Paranaíba, MG & 120 & $11(9.2)$ & $109(90.8)$ & $50(41.7)$ & $70(58.3)$ \\
\hline II & Patrocínio, MG & 445 & $9(2.0)$ & $436(98.0)$ & $238(53.5)$ & $207(46.5)$ \\
\hline III & Perdizes, MG & 35 & $0(0.0)$ & $35(100.0)$ & $23(65.7)$ & $12(34.3)$ \\
\hline Total & & 600 & $20(3.3)$ & $580(96.7)$ & $311(51.8)$ & $289(48.2)$ \\
\hline
\end{tabular}

ming program. This study was approved by the Ethical Committe for Animal Use/Laboratory Animal Nucleus (CEUA/NAL) of Federal Fluminense University (register \#320/13).

The serological results and epidemiological variables were analyzed using EPI-info software. The agreement level between the serological tests was evaluated by agreement index Kappa (K). The association between two categorical variables was determined by Pearson qui-square test $\left(\chi^{2}\right)$. Tables formed by two rows and two columns were evaluated by Fischer test with significance level of 5\%. In order to evaluate the impact among the variables, odds ratio (OR) values were described with their respective confidence interval (CI) of $95 \%$.

\section{RESULTS}

\section{Occurrence}

All samples were submitted to IHA test and IFAT for detection of antibodies anti-T. gondii. These antibodies were detected in $3.3 \%(20 / 600)$ of the samples using IHA test. Seropositivity of $51.8 \%(311 / 600)$ was detected by IFAT (cutoff titer of 1:64). Considering the IHA test results, only in one farm the presence of antibodies anti-T. gondii was not detected. However, the results from IFAT showed that all farms housed positive animals (Table 1). Among the positive samples by IFAT, $96.8 \%(301 / 311)$ had antibody titer of 1:64 and only $3.2 \%(10 / 311)$ had antibody titer of $1: 256$.

The agreement index Kappa (K) between the two serological tests used in this study was 0.03 (Table 2). According to Landis \& Koch (1977) this value indicates a weak agreement between these two techniques for the detection of anti-T. gondii antibodies. Therefore, for data analysis only the samples positive in IFAT test were used since this test is considered the gold standard to detect the serological occurrence in pigs. The use of IFAT as a gold standard me-

Table 2. Comparison between serological techniques (IHA and IFAT) for anti-Toxoplasma gondii anti body detection in serum samples from pigs slaughtered in Triângulo Mineiro region-MG during May-July 2014

\begin{tabular}{lccl}
\hline IHA & \multicolumn{3}{c}{ IFAT } \\
\cline { 2 - 4 } & Positive & Negative & Total \\
\hline Positive & 15 & 5 & 20 \\
Negative & 296 & 284 & 580 \\
Total & 311 & 289 & 600
\end{tabular}

Table 3. Occurrence of anti-T. gondii antibodies in serum samples of pigs slaughtered in Triângulo Mineiro-MG during May-July 2014, according to the risk factors for Toxoplasma gondii infection

\begin{tabular}{|c|c|c|c|c|c|c|}
\hline Variable & $\begin{array}{c}\text { Reactive } \\
\mathrm{n}(\%)\end{array}$ & $\begin{array}{c}\text { Non-Reactive } \\
n(\%)\end{array}$ & $\begin{array}{l}\text { Total } \\
\mathrm{n}(\%)\end{array}$ & OR & CI 95\% & P value \\
\hline \multicolumn{7}{|l|}{ Sex } \\
\hline Male & $142(49.1)$ & $147(5.9)$ & $289(100.0)$ & 0.81 & $(0.59-1.12)$ & 0.202 \\
\hline Female & $169(54.3)$ & $142(45.7)$ & $311(100.0)$ & 1.23 & $(0.89-1.70)$ & \\
\hline Total & 311 (51.8) & $289(48.2)$ & $600(100.0)$ & & & \\
\hline \multicolumn{7}{|l|}{ Lineage } \\
\hline $\mathrm{ADB}^{*}$ & $238(53.5)$ & $207(46.5)$ & $445(100.0)$ & - & - & \\
\hline Agroceres PIC & $50(41.7)$ & $70(58.3)$ & $120(100.0)$ & 0.62 & $(0.41-0.93)$ & 0.017 \\
\hline No information & $23(65.7)$ & $12(34.3)$ & $35(100.0)$ & 1.67 & $(0.81-3.43)$ & \\
\hline Total & 311 (51.8) & $289(48.2)$ & $600(100.0)$ & & & \\
\hline \multicolumn{7}{|l|}{ Collective raising } \\
\hline Yes (Bovines) & $50(41.7)$ & $70(58.3)$ & $120(100.0)$ & 0.6 & $0.40-0.90$ & 0.013 \\
\hline No & $261(54.4)$ & $219(45.6)$ & $480(100.0)$ & & & \\
\hline Total & 311 (51.8) & $289(48.2)$ & $600(100.0)$ & & & \\
\hline \multicolumn{7}{|l|}{ Farm size } \\
\hline Medium & $50(41.7)$ & $70(58.3)$ & $120(100.0)$ & 0.6 & $0.40-0.90$ & \\
\hline Large & $261(54.4)$ & $219(45.6)$ & $480(100.0)$ & 1.67 & $1.11-2.50$ & 0.013 \\
\hline Total & 311 (51.8) & $289(48.2)$ & $600(100.0)$ & & & \\
\hline \multicolumn{7}{|c|}{ Presence of Rodents } \\
\hline Yes & $50(41.7)$ & $70(58.3)$ & $120(100.0)$ & 0.6 & $0.40-0.90$ & 0.013 \\
\hline No & $261(54.4)$ & $219(45.6)$ & $480(100.0)$ & & & \\
\hline Total & 311 (51.8) & $289(48.2)$ & $600(100.0)$ & & & \\
\hline \multicolumn{7}{|l|}{ Type of Water } \\
\hline Treated & $261(54.4)$ & $219(45.6)$ & $480(100.0)$ & 1.67 & $1.11-2.50$ & 0.013 \\
\hline Well or Creek & 50 (41.7) & $70(58.3)$ & $120(100.0)$ & 0.6 & $0.40-0.90$ & \\
\hline Total & 311 (51.8) & $289(48.2)$ & $600(100.0)$ & & & \\
\hline
\end{tabular}

*Reference category for OR calculation. 
thod to detect toxoplasmic infection in pigs was validated by Minho et al. (2004) by detecting anti-T. gondii antibodies in 46 experimentally infected pig serum with a sensitivity of $95.7 \%$ and specificity of $97.8 \%$. Fialho \& Araújo (2002) compared the IFAT and HAI techniques and concluded that for diagnosis purposes the IFAT is superior to HAI, and thus more adequate for epidemiological surveys.

\section{Herd and management characteristics}

All pig farms were located in rural areas of TriânguloMineiro region and used an intensive raising system. The farms located at Patrocínio and Perdizes were considered large in size while the other farm located at Carmo do Paranaíba was considered medium. The presence of cats was not detected in any of the farms studied. However, the presence of rodents was reported in the farm located at Carmo do Paranaíba. In this same farm the collective raising with bovines was also reported. The occurrence of positive animals for anti-T.gondiiantibodies was higher in the farm located at Perdizes (65.7\%, $\mathrm{p}=0.017)$.

Athough the percentage of infected female by T. gondii $(54.3 \%)$ was, in absolute numbers, higher than the percentage of infected male (49.1\%), there was no difference between the mean number of infected males and females $(\mathrm{p}=0.202)$.

Regarding the lineage of the pigs, it was observed that $76.5 \%(238 / 311)$ of the positive pigs were from ADB lineage, $16.1 \%$ (50/311) from Agroceres PIC lineage, and 7.4\% $(23 / 311)$ were from unknown lineage. The association between infection by T. gondii and lineage of the animals was significant $(p=0.017)$. However, the frequency of infection was directly proportional in relation to the total number of samples per lineage.

The evaluation of the risk factors related to T. gondii transmission to pigs, showed that among positive pigs 83.9\% (261/311) were not raised with other animal species and the presence of rodents was not reported in the farm of origin $(\mathrm{p}=0.013)$. Among reactive samples, $83.9 \%$ (261/311) were from farm of large size that offered treated water (water from public supply companies) to animals and $16.1 \%$ (50/311) were from farm of medium size that offered well or creek water to the animals. The odds of seropositivity among pigs raised in large farms that offered treated water were 1.67 higher than those raised in medium farms that offered well or creek water to the animals. All the variables observed had statistical significance $(\mathrm{p}=0.013)$ (Table 3).

\section{DISCUSSION}

In spite of the fact that it is not possible to determine the exact importance of production animals in toxoplasmosis transmission to humans, it is known that pig meat represents the major infection source in many countries. To our knowledge there are no studies about Toxoplasma gondii infection in pigs raised in Triângulo Mineiro region. In Brazil, although the consumption of pig meat is lower than other kind of meat (bovine and poultry) there is a risk of $T$. gondii infection, especially if sanitary care were not taken during pig farming. The habits of the consumers also put them at risk of infection (Schlindwein \& Kassouf 2006, Silva et al. 2010).

The Kappa value found in this study (0.003) demonstrated a weak association between IHA test and IFAT to detect antibodies anti-T. gondii in pigs. This result differs from a previous study performed at Rio de Janeiro that found $100 \%$ agreement in cats (Barros et al. 2015). Therefore, the IHA test kit for human toxoplasmosis diagnosis must be standardized for other animal species before its use in epidemiological studies.

Our occurrence data corroborates with similar studies performed in other Brazilian states such as Pará (50.0\%; Freitas et al. 2009) and São Paulo (48.0\%; Villalobos et al. 2011). However, the occurrence of toxoplasmosis in pigs found in this study was higher than those observed in previous studies: 36.2\% in Paraíba (Azevedo et al. 2010); 26.9\% in Alagoas (Valença et al. 2011); 18.2\% in Bahia (Bezerra et al. 2009); 12.8\% in Mato Grosso (Muraro et al. 2010); 12.6\% in Paraná (Santos et al. 2015) and 12.5\% in Pernambuco (Fernandes et al. 2012). But was lower than observed in Rio de Janeiro (65.8\%; Bonna et al. 2006) and Rio Grande do Sul (86.0\%; Silva et al. 2003). The comparison between the present study and the results obtained by other authors should be done with caution. Brazil is a country of continental dimensions, with different climate and environmental conditions, sometimes very specific, a factor that could explain the observed differences when comparing our results with those published by others. Moreover, other relevant points that should be considered are the type of raising system (intensive, semi-intensive or extensive), the different serological methods used for diagnosis or the different cut off points employed, and thus differences on sensitivity of each technique should be considered.

The occurrence of T. gondii infection in pigs observed on the present study calls into question the health of consumers, especially those who eat raw or undercooked meat. The absence of serological exams on slaughtered animals allows the products to be freely marketed, without inspection, since it is not possible to detect the presence of the parasite on the slaughter line. This scenario points to the need for animal health planning on the production chain origin, and the awareness of producers for ways to control this disease (adequate management practices, control of rodents and felines on proprieties, health education) to transform the product in a positive factor for animal and collective health, and also to meet the health requirements.

Regarding the correlation between positivity for T. gondii infection and animal origin, despite the greater number of animals from Patrocínio, the positive animal rate for toxoplasmosis was higher in Perdizes. This association was significant $(\mathrm{p}=0.017)$ and the odds for seropositivity in this farm was 2.68 higher than observed in other farms. However, this information should be observed with caution, due to the small number of proprieties, which could have influenced in some statistical associations, and also the sampling varied between proprieties. Variation of positive frequency among farms (41.7 to $65.7 \%$ ) corroborate with a previous study performed in another state (Goiás) that observed a variation 
between $8.33 \%$ and $60 \%$ in the 40 farms evaluated (Matos et al. 1999). However, this greater variation can be related to the greater number of farms studied. This variation can occur mainly due to the variety of risk factors present among the counties which can have different ecosystems or in different farms from the same county which can have different management measures that can favor T. gondii infection (Suaréz-Aranda et al. 2000, Caporali et al. 2005).

The animal gender did not affect the rate of positive. This data is similar to other study that observed that both genders were exposed to the same risk factors (Azevedo et al. 2010). According to Garcia et al. (1999) the animal breed or genetics can contribute to variation observed in the occurrence of T. gondii infection. In the present study a significant association was observed between seropositivity and the animal lineage, however, the higher percentage observed on ADB lineage could be due to a higher number of these animals on the sample used in this study, and not necessarily due to intrinsic factors of this lineage.

The destination of the pig after slaughter and the infection occurrence did not showed statistical difference $(\mathrm{p}=0.171)$. However, most of the positive pigs were used to make meat products, which alert us to the great number of infected animals used as human food. In this regard, several researches had detected T. gondii presence in pig meat products. The presence of $T$. gondii was confirmed in $8.72 \%(13 / 149)$ of the swine sausage samples in Londrina-PR (Dias et al. 2005). In pigs slaughtered in small and medium slaughterhouses in Erechim/RS (southern Brazil), $34 \%(17 / 50)$ of the diaphragm samples and $66 \%(33 / 50)$ of the tongue samples were positive for T. gondii (Belfort-Neto et al. 2007).

In the present study, pig raising collectively with other animal species (bovine) did not represent risk of infection by T. gondii, actually it represented a protective factor (OR=0.6, CI 95\%, 0.40-0.90). This was probably due to the management measures adopted in the farm and not due to the collective raising per se.

The chance of infection by T. gondii was 1.67 times higher in large farms than in medium ones (OR=1.67, CI 95\%, 1.11-2.50). The use of intensive raising systems (confined animals) reduced pig exposition to T. gondii when compared to semi-confined animals (AFSSA 2005). In our study, however, the great occurrence found in pigs raised in feedlot system and the greater risk to acquire T. gondii infection in large farm could be explained by the greater animal density in the larger farms. Management factors such as water in the piggery, groove drinking fountain and flooded areas in the farm were also associated with a higher prevalence of toxoplasmosis (Tsutsui et al. 2003).

All animals used in the present study were fed with ration. This feeding system can be directly related to a high occurrence of $T$. gondii infection in pigs (Vidotto et al. 1990). In the intensive raising systems, the ration is storaged for a longer period, increasing the risk of contamination of food by T. gondii oocysts from cats. In the present study the presence of cats was not reported in the farms evaluated, however, we must consider that some bias could have occurred during questionnaire answer.
The water is an important source of infection by T. gondii oocysts (Jones \& Dubey 2010). In the present study, two farms offered water from wells or creeks to their animals. Unexpectedly, the use of treated water (water from public supply companies) increased the chances for $T$. gondii infection (OR $=1.67$, CI 95\%, 1.11-2.50). This result indicated an event that was not detected by the present study and points out the need for further investigation. However, a justification for such an event would be a probable inadequacy or fail on treatment of water that is destined to animals or the contamination of water from drinkers and reservoirs by parasite sporulated oocysts.

The presence of rodents on pig farms was described by Valença et al. (2011) as a risk factor not only because rats attract cats, which could eliminate oocysts in their feces and contaminate the environment, but also because these animals could be infected by ingesting rodents with tissue cysts. Although the presence of rodents did not represent risk for pig infection in the present study (OR=0.6, CI 95\%, $0.40-0.90$ ), the epidemiological questionnaire revealed that $41.7 \%$ of the animals from the farm with rodent presence were positive for T. gondii, which suggests a participation of the rodents in pig infection. In addition, a bias regarding the presence of rodents could have happened during questionnaire answer. Moreover, the observation of rodents only on the medium size propriety could be related to the fact that, in larger proprieties, could be more difficult to identify the presence of these animals, because of an extensive area making it difficult for the owners to observe the rodents.

Although the presence of cats was not reported, this did not exclude the unnoticed presence of stray cats that could have contaminated the ration or the environment with $T$. gondii oocysts.

\section{CONCLUSIONS}

The prevalence of Toxoplasma gondii infection was $51.8 \%$ in pigs by IFAT, which demonstrates the importance of these animals as infection sources for humans by ingestion of raw or undercooked meat or meat products.

Positive association ( $p>0.05$ ) of epidemiological variables (farm size, type of drinking water and presence of rodents) were important factors for T. gondii transmission in the studied area. Thus improvements on raising techniques could reduce T. gondii infection sources on pig herds.

Acknowledgements.- The authors thank CAPES for financial support.

Conflict of interest.- The authors declare no conflicts of interest and that they are responsible for the content and writing of this article.

\section{REFERENCES}

AFSSA 2005. Toxoplasmose: état des connaissances et évaluation du risque lié à l'alimentation. Rapport du groupe de travail "Toxoplasma gondii" de l'Affsa. Agence Française de Sécurité Sanitairedes Aliments. Maisons-Alfort, France. 318p.

Almeida W.M., Miranda Z.B., Flausino W., Coelho C.D, Fonseca A.B.M. \& Lopes C.W.G. 2015. Suínos sororreagentes a Toxoplasma gondii (Apicomplexa: Toxoplasmatinae) enviados para abate e destinados ao consumo humano. Revta Bras. Med. Vet. 37(4):397-400.

Amendoeira M.R.R., Costa T. \& Spalding S.M. 1999. Toxoplasma gondii Ni- 
colle et Manceaux, 1909 (Apicomplexa: Sarcocystidae) e a Toxoplasmose. Revta Souza Marques 19(1):15-35.

Azevedo S.S., Pena H.F.J., Alves C.J., Melo Guimarães Filho A.A., Oliveira R.M., Maksimov P., Schares G. \& Gennari S.M. 2010. Prevalence of anti-Toxoplasma gondii and anti-Neospora caninum antibodies in swine from Northeastern Brazil. Revta Bras. Parasitol. Vet.19:80-84.

Barros R.S., Menezes R.C., Pereira S.A., Figueiredo F.B., Oliveira R.V.C., Nicolau J.L., Neves L.B., Millar P.R., Kitada A.A.B. \& Amendoeira M.R.R. 2015. Feline sporotrichosis: coinfection with Toxoplasma gondii, Feline Immunodeficiency Virus and Feline Leukemia Virus in cats from an endemic area in Brazil. Acta Scientiae Veterinariae 43(316):1-6.

Belfort-Neto R., Nussenblatt V., Rizzo L., Muccioli C., Silveira C., Nussenblatt R., Khan A., Sibley L.D. \& Belfort Jr R. 2007. High prevalence of unusual genotypes of Toxoplasma gondii infection in pork meat samples from Erechim, southern Brazil. Anais Acad. Bras. Ciências 79:111-114.

Bezerra R.A., Paranhos E.B., Del'arco A.E. \& Albuquerque G.R. 2009. Detecção de anticorpos anti-Toxoplasmagondii em suínos criados e abatidos no Estado da Bahia, Brasil. Revta Bras. Parasitol. Vet. 18:78-80.

Bonna I.C.F., Figueiredo F.B., da Costa T., Vicente R. T., Santiago C.A.D., Nicolau J.L., Neves L.B., Millar P.R., Sobreiro L.G. \& Amendoeira M.R.R. 2006. Estudo soroepidemiológico da infecção por Toxoplasma gondii em suínos e frangos, para abate, em região rural do Rio de Janeiro. Revta Bras. Ciênc. Vet. 13:186-189.

Camargo M.E. 1964. Improved technique of indirect immunofluorescence for serological diagnosis of toxoplasmosis. Revta Inst. Med. Trop. São Paulo 6:117-118.

Caporali E.H.G., Silva A.V., Mendonça A.O. \& Langoni H. 2005. Comparação de métodos para determinação da prevalência de anticorpos anti-Toxoplasmagondii em suínos dos Estados de São Paulo e Pernambuco, Brasil. Arqs Ciênc. Vet. Zoologia Unipar 8:19-24.

Dias R.A.F., Navarro I.T., Ruffolo B.B., Bugni F.M., Castro M.V. \& Freire R.L. 2005. Toxoplasma gondii em linguiça de carne suína tipo frescal, com investigação soroepidemiológica em trabalhadores de estabelecimentos produtores. Revta Inst. Med. Trop. São Paulo 47(4):185-189.

Dubey J.P., Hill D.E., Jones J.L., Hightower A.W., Kirkland E., Roberts J.M., Marcet P.L., Lehmann T., Vianna M.C., Miska K., Sreekumar C., Kwok O.C., Shen S.K. \& Gamble H.R. 2005. Prevalence of viable Toxoplasma gondii in beef, chicken, and pork from retail meat stores in the United States: risk assessment to consumers. J. Parasitol. 91(5):1082-1093.

Dubey J.P. \& Jones J.L. 2008. Toxoplasma gondii infection in humans and animals in the United States. Int. J. Parasitol. 38:1257-1278.

Dubey J.P. 2009. Toxoplasmosis in pigs: the last 20 years. Vet. Parasitol. 164:89-103.

Elmore S.A., Jones J.L., Conrad P.A., Patton S., Lindsay D.S. \& Dubey J.P. 2010. Toxoplasma gondii: epidemiology, feline clinical aspects, and prevention. Trends Parasitol. 26:190-196.

Fajardo H.V., D’Ávila S., Bastos R.R., Cyrino C.D., Detoni M.L., Garcia J.L., Neves L.B., Nicolau J.L. \& Amendoeira M.R.R. 2013. Seroprevalence and risk factors of toxoplasmosis in cattle from extensive and semi-intensive rearing systems at Zona da Mata, Minas Gerais state, Southern Brazil. Parasites Vectors 6(191):1-8.

Fernandes E.F.T.S., Fernandes M.F.T.S., Kim P.C.P., Albuquerque P.P.F., de Souza Neto O.L., Santos A.S., Moraes E.P.B.X., Morais E.G.F. \& Mota R.A. 2012. Study of Toxoplasma gondii in slaughtered swine in the state of Pernambuco, Brazil. J. Parasitol. 98(3):690-691.

Fialho C.G. \& Araújo F.A.P. 2002. Comparação entre os testes de imunofluorescência indireta e hemaglutinação indireta para detecção de anticorpos anti-Toxoplasmagondii em soros de suínos. Acta Scientiae Veterinariae 30(3):185-189.

Freitas J.A., Oliveira J.P., Ramos O.S. \& Ishizuka M.M. 2009. Frequência de anticorpos anti-Toxoplasma gondii em suínos abatidos sem inspeção em Belém. Arq. Bras. Med. Vet. Zootec. 61(5):1230-1232.

Garcia J.L., Navarro I.T., Ogawa L. \& Oliveira R.C. 1999. Soroprevalência de Toxoplasma gondii em suínos, bovinos, ovinos e equinos e sua correlação com humanos, felinos e caninos, oriundos de propriedades rurais do norte do Paraná, Brasil. Ciência Rural 29(1):91-97.
Guimarães A.M., Ribeiro M.F.B., Lima J.D. \& Almeida T.M.B. 1992. Frequência de anticorpos anti-Toxoplasma gondii em suínos da raça Piau. Arq. Bras. Med. Vet. Zootec. 44:69-71.

IBGE 2012. Produção da Pecuária Municipal 2012. Vol.40. Instituto Brasileiro de Geografia e Estatística, Rio de Janeiro, Brasil. 71p.

IBGE 2014. Produção da Pecuária Municipal 2014. Vol.42. Instituto Brasileiro de Geografia e Estatística, Rio de Janeiro, Brasil. 39p.

Jiang W., Sullivan A.M., Su C. \& Zhao X. 2012. An agent-based model for the transmission dynamics of Toxoplasma gondii. J. Theoretical Biology 293:15-26.

Jones J.L. \& Dubey J.P. 2010. Waterborne toxoplasmosis: recent developments. Exp. Parasitol. 124:10-25.

Landis J.R. \& Koch G.G. 1977. The measurement of observer agreement for categorical data. Biometrics 33:159-174.

Matos M.P.C., Miguel M., Moura V.M.B.D., Sobestiansky J. \& Brito L.A.B. 1999. Anticorpos para Toxoplasma gondii em soros de matrizes suínas de granjas que abastecem o mercado consumidor de Goiânia. Hora Vet. 19(109):9-11.

Millar P.R., Sobreiro L.G., Bonna I.C.F. \& Amendoeira M.R.R. 2008. A importância dos animais de produção para a infecção por Toxoplasma gondii no Brasil. Semina, Ciênc. Agrárias 29(3):693-706.

Minho A.P., Freire R.L., Vidotto O., Gennari S.M., Manara E.M., Garcia J.L. \& Navarro I.T. 2004. Avaliação dos testes de Reação de Imunofluorescência indireta e aglutinação modificada para a detecção de anticorpos anti- Toxoplasma gondii em suínos infectados experimentalmente. Pesq. Vet. Bras. 24(4):199-202.

Muraro L.S., Caramori Jr J.G., Amendoeira M.R.R., Pereira J.A., Filho J.X., Vicente R.T., Neves L.B., Nicolau J.L., Igarashi M. \& Moura S.T. 2010. Seroprevalence of Toxoplasma gondii infection in swine matrices in Nova Mutum and Diamantino, Mato Grosso, Brazil. Revta Bras. Parasitol. Vet. 19(4):254-255.

Passos L.M.F., Lima J.D. \& Figueiredo B.L. 1984. Frequência de anticorpos anti-Toxoplasma gondii em suínos abatidos em Belo Horizonte, Minas Gerais. Arq. Bras. Med. Vet. Zootec. 36:649-657.

Pezerico G.B., Pezerico S.B., Silva R.C., Hoffmann J.L., Camargo L.B. \& Langoni H. 2007. Ocorrência de anticorpos anti-Toxoplasmagondii e anti-Leptospira spp. em suínos abatidos em três abatedouros dos estados de Minas Gerais e São Paulo. Arqs Inst. Biológico, São Paulo, 74:267-270.

Sabin A.B. 1941. Toxoplasmic encephalitis in children. J. Am. Med. Assoc. 116:801-807.

Santos H.L.P.L., Freire R.L., Merlini L.S., Sposito P.H., Lima J.S. \& Navarro I.T. 2015. Occurrence of infection by Toxoplasma gondii in slaughtered swine in the northwestern region of Paraná, Brazil. Semina, Ciênc. Agrárias 36(3):1999-2004.

Sawadogo P., Hafid J., Bellete B., Sung R.T.M., Chakdi M., Flori P., Raberin H., Hamouni I.B., Chait A. \& Dalal A. 2005. Seroprevalence of Toxoplasma gondii in sheep from Marrakech, Morocco. Vet. Parasitol. 130(1/2):8992.

Schenk M.A.M., Lima J.D. \& Schenk J.A.P. 1977. Isolamento de Toxoplasma gondii em suínos do estado de Minas Gerais. Arqs Esc. Vet. UFMG 29:2530.

Schlindwein M.M \& Kassouf A.L. 2006. Análise da influência de alguns fatores socioeconômicos e demográficos no consumo domiciliar de carnes no Brasil. Revta Economia Sociologia Rural 44(3):549-572.

Silva A.V., Silva R.C., Zamprogna T.O. \& Lucas T.M. 2010. Toxoplasma gondii em suínos com ênfase na contribuição brasileira. Scientia Medica 20(1):120-130.

Silva R.A.M.S., Bonassi C., Dalla Costa O.A. \& Morés N. 2003. Serosurvey on toxoplasmosis in outdoor pig production systems of the southern region of Brazil. Revue d'Élevage Méd. Vét. Pays Tropicaux 56:145-147.

Sousa R.A., Lemos J.F., Farias L.A., Lopes C.D. \& Santos K.R. 2014. Seroprevalence and risk factors for Toxoplasma gondii infection in pigs in southern Piauí. J. Vet. Parasitol. 23(1):98-100.

Suaréz-Aranda F., Galisteo A.J., Hiramoto R.M., Cardoso R.P.A., Meireles L.R., Miguel O. \& Andrade Jr H.F. 2000. The prevalence and avidity of 
Toxoplasma gondii IgG antibodies in pigs from Brazil and Peru. Vet. Parasitol. 91:23-32.

Tsutsui V.S., Navarro I.T., Freire R.L., Freitas J.C., Prudencio L.B., Delba A.C.B. \& Marana E.R.M. 2003. Soroepidemiologia e fatores associados à transmissão de Toxoplasma gondii em suínos do norte do Paraná. Archs Vet. Sci. 8:27-34.

Valença R.M.B., Mota R.A., Anderlini G.A., Faria E.B., Cavalcanti E.F.S.T.F., Albuquerque P.P.F., Souza Neto O.L. \& Guerra M.M.P. 2011. Prevalência e fatores de risco associados à infecção por Toxoplasma gondii em granjas suinícolas tecnificadas no Estado de Alagoas. Pesq. Vet. Bras. 31(2):121-126.
Vidotto O., Costa A.J., Balarin M.R.S. \& Rocha M.A. 1990. Estudos epidemiológicos da toxoplasmose em suínos da região de Londrina/PR. Semina, Ciênc. Agrárias 11:53-59.

Villalobos E.M.C., Felício P.S., Lara M.C.C.S.H., Cunha E.M.S., Ogata R.A. \& Bersano J.G. 2011. Frequência de anticorpos anti-Toxoplasmagondii em soros de suínos de propriedades rurais do estado de São Paulo, Brasil. Biológico 73:129-180.

Yu J., Xia Z., Liu Q., Liu J. \& Zhang W. 2007. Seroepidemiology of Neospora caninum and Toxoplasma gondii in cattle and water buffaloes (Bubalus bubalis) in the People's Republic of China. Vet. Parasitol. 143:79-85. 